\title{
Multi-element Analysis of Ferromanganese Nodules and Crusts by Inductively Coupled Plasma Mass Spectrometry
}

\author{
Xiaoyuan Wang ${ }^{\mathrm{a}, \mathrm{b}, \mathrm{c}}$, Xuebo Yin ${ }^{\mathrm{a}, \mathrm{c}}$, Zhigang Zeng, ${ }^{\mathrm{a}, \mathrm{b}, \mathrm{c}}$, and Shuai Chen ${ }^{*, a, b, c}$ \\ a Key Laboratory of Marine Geology and Environment, Institute of Oceanology, \\ Chinese Academy of Sciences, Qingdao 266071, P.R. China \\ ${ }^{b}$ Laboratory for Marine Mineral Resources, Qingdao National Laboratory for \\ Marine Science and Technology, Qingdao 266071, P.R. China \\ ${ }^{c}$ Center for Ocean-Mega Science, Chinese Academy of Sciences, Qingdao 266071, P.R. China
}

\section{INTRODUCTION}

Ferromanganese nodules and crusts occur globally throughout the ocean, and on seamounts and plateaus (1-3). They have been systematically investigated over several decades because of their strategic and critical metals of interest (Bi, Co, Li, Mo, Nb, Ni, Th, W, Zr, and rare earth elements) (3-8) and their potentials for recording paleoceanographic, depositional, and geological environmental changes (8-11). Ferromanganese nodules and crusts typically occur as layered concretions (12), and their individual sublayers may have distinct chemical compositions formed via different growth processes $(8,13)$. Therefore, recent studies have focused on the analysis of their individual layers $(5,14,15)$, which requires use of only a small amount of sample rather than bulk sampling.

A variety of analytical techniques have been used for the determination of the elemental concentration in ferromanganese nodules and crusts including atomic absorption spectrometry (16-28), neutron activation analysis (22, 29-31), X-ray fluorescence $(3,32-34)$, and inductively coupled plasma optical emission spectrometry $(5,10,14,15$, $26,35,36)$. Since the 1990 s, inductively coupled plasma mass spectrometry (ICP-MS) has become one of the most powerful techniques used to determine the elemental

*Corresponding autbor.

E-mail: chenshuai@qdio.ac.cn

\section{ABSTRACT}

A method has been developed for the determination of minor, trace, and rare earth elements in ferromanganese nodules and crusts using a novel closed digestion bomb with ICP-MS. This bomb has a double inner arc seal design providing an effective acid circulation, and the upper part of the inner tube plugs tightly into the top of the lower part which prevents any leakage of the acid. The accuracy and precision of the analytical method was tested by analyzing four nodule reference materials. The results agreed to within $\pm 5 \%$ for about 34 of 38 elements studied, for which certified or literature values were available. The precision was better than $\pm 5 \%$. This method was applied to the analysis and research of ferromanganese nodule and crust samples obtained from the Gagua Ridge and the Northern South China Sea.

composition in ferromanganese nodules and crusts (37-49) due to its high sensitivity, large dynamic linear range and multi-element capabilities, which are superior to most conventional techniques (5060). Since the technique requires samples in their dissolved form, considerable effort is required to develop simpler and morerapid sample preparation procedures. A number of different digestion procedures for ferromanganese nodules and crusts have been reported in the literature with the majority of them relying on tradi- tional hot plate digestion and using a combination of various acids, such as $\mathrm{HCl}-\mathrm{HNO}_{3}(44), \mathrm{HCl}-\mathrm{HNO}_{3}-$ $\mathrm{HF}(8,15,35,42,47,61-63)$, HCl$\mathrm{HNO}_{3}-\mathrm{HF}_{2} \mathrm{H}_{2} \mathrm{O}_{2}$ (38), $\mathrm{HNO}_{3}$-HF$\mathrm{HClO}_{4}$ - aqua regia $(7,9,33,48)$, $\mathrm{HNO}_{3}$-HF-HClO 4 (5), $\mathrm{HCl}-\mathrm{HNO}_{3}$-HF$\mathrm{HClO}_{4}(32,41,44,65,66)$, and $\mathrm{HCl}-$ $\mathrm{HNO}_{3}-\mathrm{HF}-\mathrm{HClO}_{4}$-aqua regia (34) in a Teflon ${ }^{\circledR}$ vessel, followed by ICPMS analysis. The use of large volumes of acids or a combination of various acids, or multiple evaporation and dissolution steps, carries the risk of contamination, precipitation losses and spectral interference. Therefore, the analytical requirements for an optimal digestion procedure include accurate and precise data for as many elements as possible, use of small sample size, and provide high sample throughput. A high-pressure digestion technique has been generally applied (38, 42, 67-69). However, acid leakage often occurs during the digestion process, which may leave undissolved residue.

In this study, the traditional highpressure digestion technique has been improved by using a corrosive-resistant digestion bomb with a double inner arc seal design. The bomb has a tight seal and offers effective circulation of the acid during the digestion process. A small amount of the ferromanganese nodule and crust sample can be digested directly at high temperature and pressure, which speeds up the digestion process and improves the dissolution effect. This sample digestion method is practical and simple, and can deal with 100 sam- 
ples simultaneously. It was successfully applied to the analysis and study of ferromanganese nodule and crust samples obtained from the Gagua Ridge and the Northern South China Sea $(8,63)$.

\section{EXPERIMENTAL}

\section{Instrumentation}

An ELAN ${ }^{\circledR}$ DRCII'TM ICP-MS $^{\text {TM }}$ (PerkinElmer, Inc., Shelton, CT, USA) was used for sample analysis at the Institute of Oceanology, Chinese Academy of Sciences. The instrumental parameters used for the determination of minor, trace, and rare earth elements are listed in Table I. The detected isotopes were as follows: ${ }^{7} \mathrm{Li},{ }^{45} \mathrm{Sc},{ }^{51} \mathrm{~V},{ }^{52} \mathrm{Cr},{ }^{59} \mathrm{Co}$, ${ }^{60} \mathrm{Ni},{ }^{65} \mathrm{Cu},{ }^{66} \mathrm{Zn},{ }^{85} \mathrm{Rb},{ }^{86} \mathrm{Sr},{ }^{89} \mathrm{Y},{ }^{90} \mathrm{Zr}$, ${ }^{93} \mathrm{Nb},{ }^{98} \mathrm{Mo},{ }^{114} \mathrm{Cd},{ }^{133} \mathrm{Cs},{ }^{135} \mathrm{Ba}$, ${ }^{178} \mathrm{Hf},{ }^{181} \mathrm{Ta},{ }^{182} \mathrm{~W},{ }^{208} \mathrm{~Pb},{ }^{209} \mathrm{Bi},{ }^{232} \mathrm{Th}$, ${ }^{238} \mathrm{U}$ and ${ }^{139} \mathrm{La},{ }^{140} \mathrm{Ce},{ }^{141} \mathrm{Pr},{ }^{146} \mathrm{Nd}$, ${ }^{147} \mathrm{Sm},{ }^{151} \mathrm{Eu},{ }^{160} \mathrm{Gd},{ }^{159} \mathrm{~Tb},{ }^{163} \mathrm{Dy}$, ${ }^{165} \mathrm{Ho},{ }^{166} \mathrm{Er},{ }^{169} \mathrm{Tm},{ }^{172} \mathrm{Yb}$ and ${ }^{175} \mathrm{Lu}$. ${ }^{187}$ Re was used as an internal standard. The background counts for the $2 \% \mathrm{HNO}_{3}$ solutions were normally $<2$ cps.

TABLE I

Instrumental Operating

Parameters Used for ICP-MS Analysis

\begin{tabular}{|c|c|}
\hline Parameters & Value \\
\hline RF power & $1250 \mathrm{~W}$ \\
\hline Plasma gas & $15 \mathrm{~L} \mathrm{~min}^{-1}$ \\
\hline Aux gas & $1.20 \mathrm{~L} \mathrm{~min}^{-1}$ \\
\hline Nebulizer gas & $0.80 \mathrm{~L} \mathrm{~min}^{-1}$ \\
\hline Sweeps & 10 \\
\hline Readings & 1 \\
\hline Replicates & 3 \\
\hline Scan mode & Peak hopping \\
\hline $\begin{array}{l}\text { Channel } \\
\text { dwell time per sweep }\end{array}$ & $100 \mathrm{~ms}$ \\
\hline Sampling cone $(\mathrm{Pt})$ & $1.10 \mathrm{~mm}$ \\
\hline Skimmer cone $(\mathrm{Pt})$ & $0.90 \mathrm{~mm}$ \\
\hline${ }^{156} \mathrm{CeO} /{ }^{140} \mathrm{Ce}$ ratio & $2.87 \%$ \\
\hline $\mathrm{Ba}^{++} / \mathrm{Ba}^{+}$ratio & $1.13 \%$ \\
\hline
\end{tabular}

Reagents and Standards

A $10 \mathrm{mg} \mathrm{L}^{-1}$ multi-element mixed standard solution and $10 \mathrm{mg} \mathrm{L}^{-1} \mathrm{REE}$ standard solution (PerkinElmer, Inc.) were used and diluted with $2 \% \mathrm{HNO}_{3}$ to $1,5,10$, and $100 \mathrm{ng}$ $\mathrm{mL}^{-1}$, respectively. A $1000 \mathrm{mg} \mathrm{L}^{-1}$ Re standard solution (Environmental Express, USA) was diluted to 10 $\mu \mathrm{g} \mathrm{L}^{-1}$ with $2 \% \mathrm{HNO}_{3}$ and used as an internal standard. The reagents used were ultrapure $\mathrm{HNO}_{3}$ (J. T. Baker, USA), and electronic industry-grade $\mathrm{HF}$ and $\mathrm{HCl}$. Distilled water (18.2 $\mathrm{M} \Omega \cdot \mathrm{cm}$ grade) was obtained using an ULTRA IONIC ultrapure water system (ELGA, UK). Four certified manganese nodule reference samples (GBW07295, GBW07296, NOD-A-1, and NOD-P1) were obtained from the National Research Center for Geoanalysis, Chinese Academy of Geological Sciences, and the United States Geological Survey (USGS).

\section{Laboratory Ware}

A screw-top PTFE-lined, corrosive-resistant digestion bomb with a volume of $\sim 15 \mathrm{~mL}$ was used for this study (Figure 1). The upper part of the inner tube plugs into the top of the lower part, and the axial crosssection of the inner tube is oval. The inner tube was pre-cleaned with $10 \% \mathrm{HNO}_{3}$ and heated to boiling for about 12 hours at $120{ }^{\circ} \mathrm{C}$ on an electro-thermal plate, then rinsed with DI water.

\section{Sample Preparation}

A $40 \mathrm{mg}$ powdered sub-sample was weighed into the PTFE bombs and $\mathrm{HF}(0.5 \mathrm{~mL}), \mathrm{HNO}_{3}(0.5 \mathrm{~mL})$, and $\mathrm{HCl}(1.5 \mathrm{~mL})$ were added. The sealed bombs were then placed in an electric oven at $180^{\circ} \mathrm{C}$ for 12 hours. After cooling, the bombs were heated on a hot plate to evaporate to dryness, after which $\mathrm{HNO}_{3}$ $(1 \mathrm{~mL})$ and water $(1 \mathrm{~mL})$ were added. The bombs were re-sealed and placed in an electric oven at $150{ }^{\circ} \mathrm{C}$ for about 12 hours to dissolve the residue. After cooling, the sample was diluted by a factor of $\sim 1000$ using $2 \% \mathrm{HNO}_{3}$ prior to measuring the elemental composition by ICP-MS.

\section{RESULTS AND DISCUSSION}

\section{Method Efficiency}

The advantage of the corrosiveresistant digestion bomb is its double inner arc seal design, which allows the evaporating acid from the top of the inner tank to the bottom without clinging onto the tank wall, thus providing an effective circulation. The upper and lower parts of the inner tank couple tightly, and the double inner arc seal design ensures a tight seal as

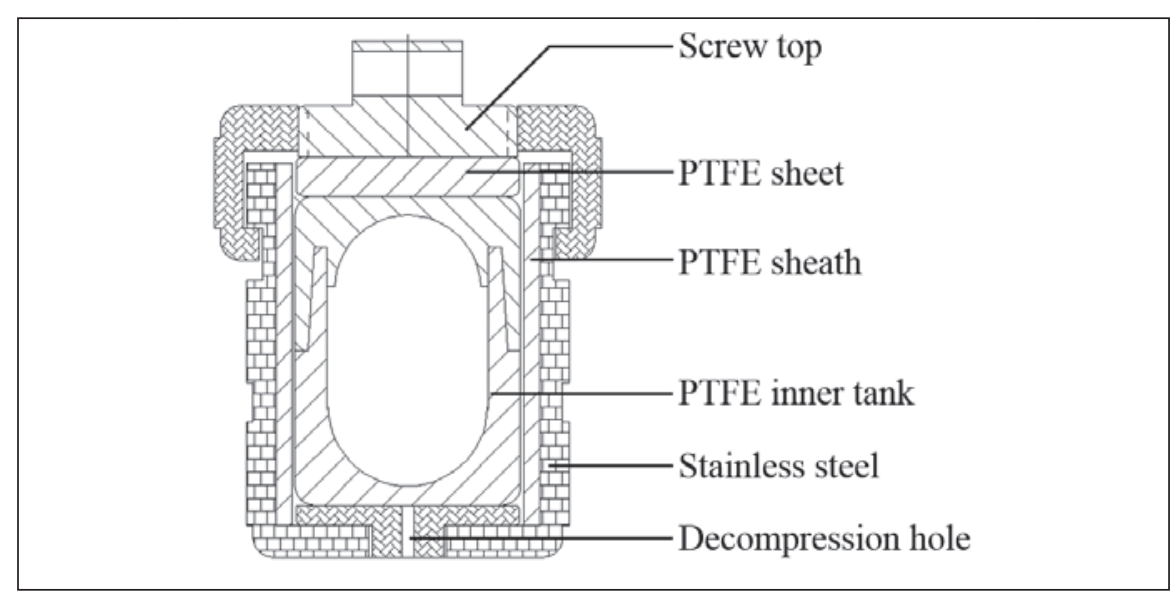

Fig. 1. Sketch of the corrosive-resistant digestion bomb (cited from reference 70 ). 
the pressure increases. This prevents any acid from leaking and avoids incomplete digestion. In comparison to previously reported methods where the ferromanganese nodule and crust samples are pretreated (Table II), the present method requires a small amount of sample $(50 \mathrm{mg})$. This will be of particular value when studying elemental distribution in the layers of the nodules and crusts, thus provide information on the growth process and the change in environmental conditions in the sampling region. The advantages of the present method include shorter digestion time than previously reported methods requiring $100 \mathrm{mg}$ samples $(9,64,47)$, reduced number of evaporation (only once), and consumes a small amount of acids (0.5 mL of HF, $0.5 \mathrm{~mL}$ of $\mathrm{HNO}_{3}$ and $1.5 \mathrm{~mL}$ of $\mathrm{HCl}$ to digest a $40 \mathrm{mg}$ sample completely) in comparison to the method which conducts an evaporation $(45,65)$, avoids risk of contamination during repeated evaporations $(7,9,38,42,44,47$, 64) and is carried by use of large volumes of acids.

The microwave-assisted digestion method (62) has the advantages of shorter digestion time and the ability to measure more than 40 elements simultaneously; however, it requires careful ventilation in a fume hood and extensive washing procedures. In contrast, this novel digestion bomb is safer and more reliable, and the digestion vessels require only a simple washing procedure. The smaller volume of the PTFE tank and the oval axial crosssection design prevent the evaporating acid to cling onto the tank wall which happened while using the larger vessels $(9,42,64)$. In addition, the use of an analogue detection mode increases the detection range of element concentrations, allowing 38 elements in the ferromanganese nodule samples to be measured at the same time without need for dilution by different factors (62). In addition, up to 100 samples can be prepared simultaneously.

\section{Interference and Correction}

The ferromanganese nodules and crusts mainly consist of iron (Fe) ( 6-7\%) and manganese (Mn) ( 26$30 \%$ ) (14). Thus, interference from Fe and Mn should be considered. Iron has four stable isotopes at the nominal masses of $54,56,57$, and 58 , with a representative isotopic composition of $5.8,91.72,2.2$, and $0.28 \%$, respectively; manganese only occurs as ${ }^{55} \mathrm{Mn}$. Most spectral interferences arise from iron, manganese, oxygen, and argon polyatomics. The mass spectra observed for the $100 \mathrm{mg} \mathrm{L}^{-1}$ iron and manganese standard solutions indicated significant interference for ${ }^{70} \mathrm{Zn}$ (interference by ${ }^{54} \mathrm{Fe}^{16} \mathrm{O}$ ), ${ }^{70} \mathrm{Ge}$ (interference by ${ }^{54} \mathrm{Fe}^{16} \mathrm{O}$ ), ${ }^{72} \mathrm{Ge}$ (interference by ${ }^{5} \mathrm{Fe}^{18} \mathrm{O}$ and ${ }^{56} \mathrm{Fe}^{16} \mathrm{O}$ ), ${ }^{73} \mathrm{Ge}$ (interference by ${ }^{57} \mathrm{Fe}^{16} \mathrm{O}$ ), ${ }^{74} \mathrm{Ge}$ (interference by ${ }^{58} \mathrm{Fe}^{16} \mathrm{O}$ ), ${ }^{71} \mathrm{Ga}$ (interference by ${ }^{55} \mathrm{Mn}^{16} \mathrm{O}$ ), ${ }^{92} \mathrm{Zr}$ (interference by ${ }^{54} \mathrm{Fe}^{38} \mathrm{Ar}$ ), ${ }^{94} \mathrm{Zr}$ (interference by ${ }^{54} \mathrm{Fe}^{40} \mathrm{Ar}$ ), ${ }^{96} \mathrm{Zr}$ (interference by ${ }^{56} \mathrm{Fe}^{40} \mathrm{Ar}$ and ${ }^{58} \mathrm{Fe}^{38} \mathrm{Ar}$ ), ${ }^{92} \mathrm{Mo}$ (interference by ${ }^{54} \mathrm{Fe}^{38} \mathrm{Ar}$ ), ${ }^{94} \mathrm{Mo}$ (interference by ${ }^{54} \mathrm{Fe}^{40} \mathrm{Ar}$ ), ${ }^{95} \mathrm{Mo}$ (interference by ${ }^{55} \mathrm{Mn}^{40} \mathrm{Ar}$ ), ${ }^{96} \mathrm{Mo}$ (interference by ${ }^{56} \mathrm{Fe}^{40} \mathrm{Ar}$ and ${ }^{58} \mathrm{Fe}^{38} \mathrm{Ar}$ ), ${ }^{97} \mathrm{Mo}$ (interference by ${ }^{57} \mathrm{Fe}^{40} \mathrm{Ar}$ ), and ${ }^{98} \mathrm{Mo}$ (interference by ${ }^{58} \mathrm{Fe}^{40} \mathrm{Ar}$ ). The interference coefficient correction method does not reduce or eliminate the interferences; therefore, the concentration of $\mathrm{Ga}$ and Ge in the ferromanganese nodule and crust sample cannot be determined accurately using the proposed method. In addition, ${ }^{66} \mathrm{Zn}$ and ${ }^{90} \mathrm{Zr}$ were selected for analysis, thus, avoiding the poly-atomic interferences. The correction formula ${ }^{98} \mathrm{Mo}_{\text {true }}={ }^{98} \mathrm{Mo}_{\text {analyzed }}-0.00618^{54} \mathrm{Fe}$ was used to correct the interference. During the analysis of the ferromanganese nodule and crust samples, the interference by Ba-oxides on the REEs was significant, i.e., of

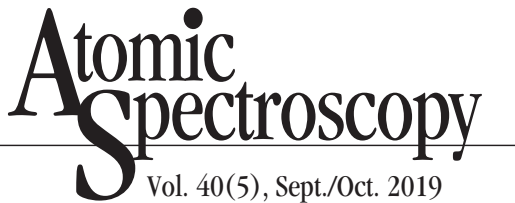

${ }^{136} \mathrm{Ba}^{16} \mathrm{O}$ on ${ }^{152} \mathrm{Sm},{ }^{135} \mathrm{Ba}^{16} \mathrm{O}$ on ${ }^{151} \mathrm{Eu}$, and ${ }^{137} \mathrm{Ba}^{16} \mathrm{O}$ on ${ }^{153} \mathrm{Eu} .{ }^{147} \mathrm{Sm}$ was selected for analysis, thus, avoiding the interference by ${ }^{136} \mathrm{Ba}^{16} \mathrm{O}$. The $\mathrm{BaO}^{+} / \mathrm{Ba}^{+}$ratio (1.873\%), obtained by the determination of a $10 \mathrm{mg} \mathrm{L}^{-1}$ Ba standard solution, and the correction formula ${ }^{151} \mathrm{Eu}_{\text {true }}=$ ${ }^{151} \mathrm{Eu}_{\text {analyzed }}-0.001873 \times{ }^{135} \mathrm{Ba}$ was used to correct the interference by the Ba-oxides on Eu.

\section{Calibration Curves and Limits} of Detection

Prior to determining the elemental composition, the ICP-MS instrument was optimized using a tuning solution containing $1 \mathrm{ng} \mathrm{m}^{\mathrm{L}-1} \mathrm{Be}$, $\mathrm{Co}, \mathrm{In}, \mathrm{Mg}, \mathrm{Ce}, \mathrm{Pb}$, and $\mathrm{U}$, and $10 \mathrm{ng} \mathrm{mL}^{-1} \mathrm{Ba}$, then calibrated using four synthetic element standard solutions of $1,5,10$, and 100 $\mathrm{ng} \mathrm{mL} \mathrm{mL}^{-1}$ in $2 \% \mathrm{HNO}_{3}$. A Re internal standard (10 $\left.\mathrm{ng} \mathrm{mL}^{-1}\right)$ was added online using a polypropylene T-connector to assess the signal drift of the instrument. It is possible to acquire analytical signals using both ion counting and analogue detection modes with automatic switching between modes at an ion current of $\sim 3$ Mcps. This allows increased dynamic range of the instrument to about nine orders of magnitude and thus, the contents of the minor and trace elements in the ferromanganese nodule and crust samples can be obtained simultaneously. The method's detection limits were defined as three times the standard deviation for 10 preparation blanks assuming a dilution factor of 1000 (Table III). The limits of detection $(3 \sigma)$ ranged from the sub-ng $\mathrm{g}^{-1}$ level up to a few $\mu \mathrm{g} \mathrm{g}^{-1}$. The precision was better than $\pm 5 \%$.

Analysis of Reference Materials and Application of the Method

In order to validate the applicability and suitability of this method, four certified manganese nodule reference samples (GBW07295, GBW07296, NOD-A-1 and NOD-P-1) 
TABLE II

Methods of Digestion Prior to ICP-MS Analysis

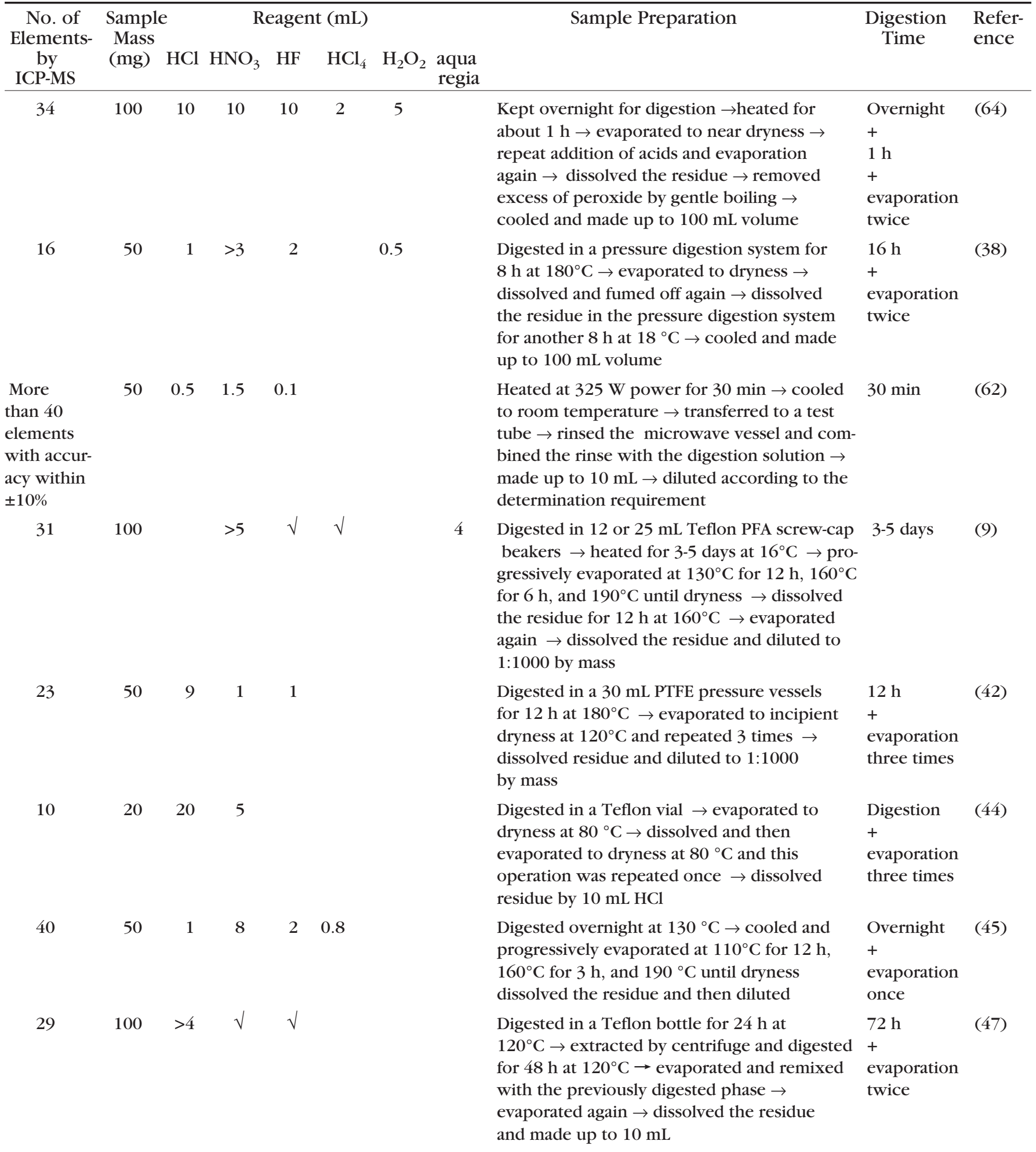

$\sqrt{ }=$ Acid was used, but there was no volume value in the reference.

(cont'd) 


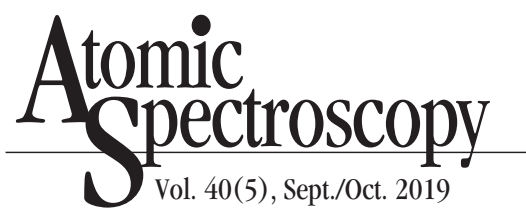

TABLE II (cont'd)

Methods of Digestion Prior to ICP-MS Analysis

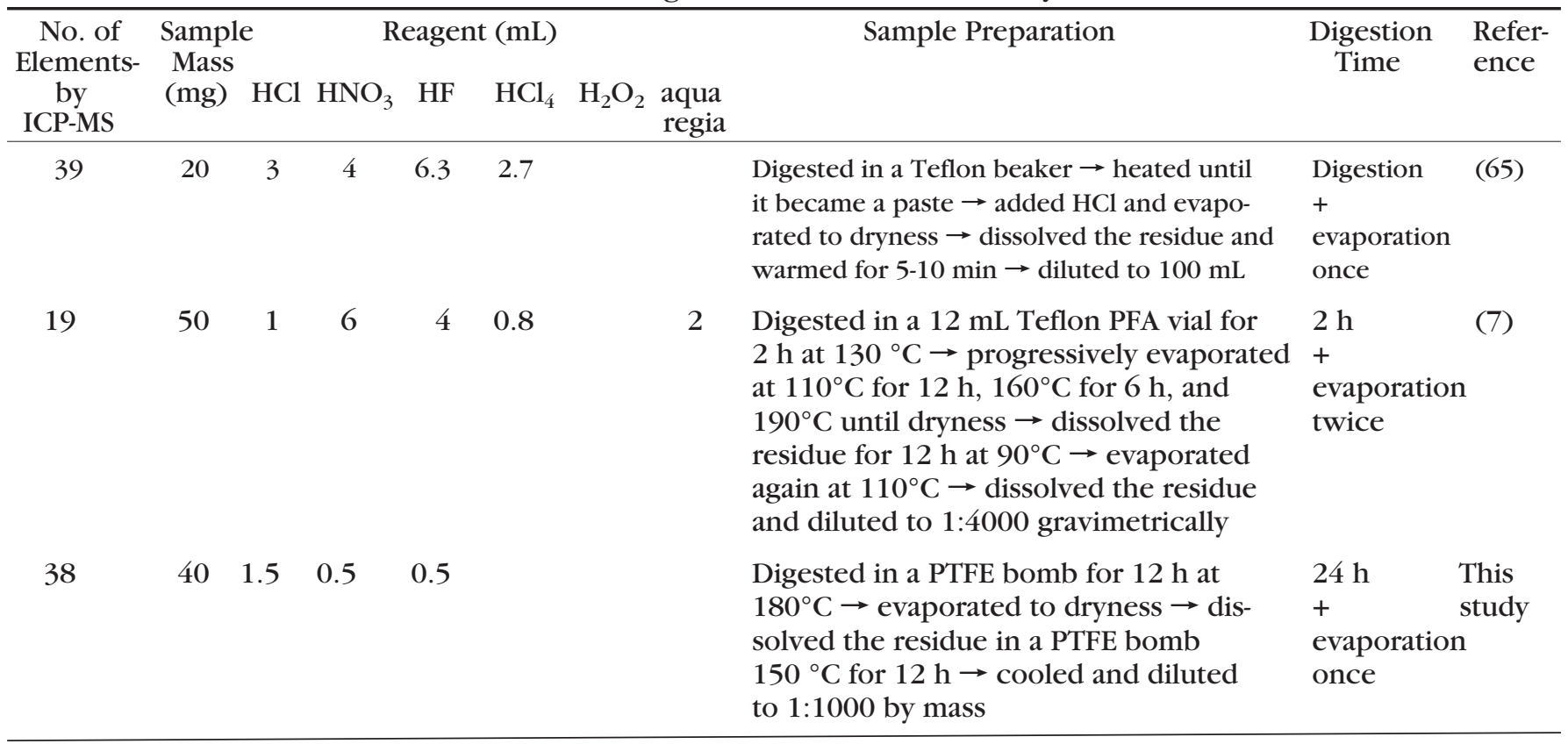

TABLE III

Detection Limits $\left(\mu \mathrm{g} \mathrm{g}^{-1}\right)$

\begin{tabular}{clll}
\hline Element & $\mathrm{DL}$ & Element & $\mathrm{DL}$ \\
\hline $\mathrm{Li}$ & 0.019 & $\mathrm{Pr}$ & 0.003 \\
$\mathrm{Sc}$ & 0.003 & $\mathrm{Nd}$ & 0.011 \\
$\mathrm{~V}$ & 0.086 & $\mathrm{Sm}$ & 0.005 \\
$\mathrm{Cr}$ & 0.013 & $\mathrm{Eu}$ & 0.001 \\
$\mathrm{Co}$ & 0.124 & $\mathrm{Gd}$ & 0.004 \\
$\mathrm{Ni}$ & 0.878 & $\mathrm{~Tb}$ & 0.0009 \\
$\mathrm{Cu}$ & 1.131 & $\mathrm{Dy}$ & 0.002 \\
$\mathrm{Zn}$ & 0.522 & $\mathrm{Ho}$ & 0.0009 \\
$\mathrm{Rb}$ & 0.007 & $\mathrm{Er}$ & 0.002 \\
$\mathrm{Sr}$ & 0.070 & $\mathrm{Tm}$ & 0.0009 \\
$\mathrm{Y}$ & 0.007 & $\mathrm{Yb}$ & 0.003 \\
$\mathrm{Zr}$ & 0.037 & $\mathrm{Lu}$ & 0.0009 \\
$\mathrm{Nb}$ & 0.007 & $\mathrm{Hf}$ & 0.001 \\
$\mathrm{Mo}$ & 0.061 & $\mathrm{Ta}$ & 0.001 \\
$\mathrm{Cd}$ & 0.006 & $\mathrm{~W}$ & 0.010 \\
$\mathrm{Cs}$ & 0.0002 & $\mathrm{~Pb}$ & 0.044 \\
$\mathrm{Ba}$ & 0.263 & $\mathrm{Bi}$ & 0.001 \\
$\mathrm{La}$ & 0.009 & $\mathrm{Th}$ & 0.005 \\
$\mathrm{Ce}$ & 0.025 & $\mathrm{U}$ & 0.001 \\
\hline
\end{tabular}

DL $=$ Detection Limit. were analyzed repeatedly, and the results are listed in Table IV. For NOD-A-1 and NOD-P-1, 18 out of 38 element concentrations were certified values, whereas other data were referenced from previously reported studies (62). Our data compare well with the values for the reference materials of GBW07295, GBW07296, NOD-A-1, and NOD-P-1, and showed that the agreement was better than $5 \%$ for 34 elements. This sample preparation method using a novel digestion bomb prior to ICP-MS analysis improves the determination of minor, trace and rare earth elements in ferromanganese nodules and crusts, and was applied to the analysis of the ferromanganese nodule and crust samples obtained from the Gagua Ridge and the Northern South China Sea $(8,63)$.

\section{CONCLUSION}

The proposed method provides quantitative information on 38 elements in ferromanganese nodules and crusts with an accuracy better than $\pm 5 \%$ for the majority of the elements studied. This method has the advantages of requiring a small amount of sample and acid as well as less evaporation, with a precision better than $\pm 5 \%$. This method was successfully applied to the analysis of ferromanganese nodule and crust samples obtained from the Gagua Ridge and Northern South China Sea.

\section{ACKNOWLEDGMENTS}

The authors are most grateful for the detailed and constructive comments and suggestions provided by the reviewers. International Science Editing checked the English translation. This research was supported by the Open Fund of the Key Laboratory of Marine Geology and Environment, Chinese Academy of Sciences (Grant Nos. MGE2019KG11 and MGE2019KG02), the Laboratory for Marine Mineral Resources, Qingdao National Laboratory for Marine Science and Technology (Grant No. MMRKF201808), the Natural Science Foundation of Shandong Province (Grant No. ZR2019QD016), the National 
TABLE IV

Results for GBW07295, GBW07296, NOD-A-1, and NOD-P-1, and

Comparison With Certified and Published Data (concentrations in $\mu \mathrm{g} \mathrm{g}^{-1}$ )

\begin{tabular}{|c|c|c|c|c|c|c|c|c|c|c|c|c|}
\hline \multirow{2}{*}{$\begin{array}{l}\text { Ele- } \\
\text { ment }\end{array}$} & \multicolumn{3}{|c|}{ GWB07295(n=10) } & \multicolumn{3}{|c|}{ GWB07296(n=10) } & \multicolumn{3}{|c|}{ NOD-A-1 $(n=10)$} & \multicolumn{3}{|c|}{ NOD-P-1 $(n=10)$} \\
\hline & Certified & Mean & RSD\% & Certified & Mean & $\mathrm{RSD} \%$ & Certified & Mean & $\mathrm{RSD} \%$ & Certified & Mean & $\mathrm{RSD} \%$ \\
\hline $\mathrm{Li}$ & $78 \pm 5$ & 79.3 & 4.2 & $205 \pm 17$ & 201 & 1.9 & $76.1 \pm 0.8^{*}$ & 72.0 & 1.5 & $140 \pm 1^{*}$ & 141 & 3.4 \\
\hline Sc & $13 \pm 1$ & 13.2 & 3.5 & $9.4 \pm 1.0$ & 9.30 & 2.1 & $12.4 \pm 0.3^{*}$ & 12.2 & 1.3 & $9.70 \pm 0.10^{*}$ & 9.32 & 0.6 \\
\hline V & $456 \pm 49$ & 453 & 4.9 & $442 \pm 51$ & 454 & 1.1 & $770 \pm 6$ & 779 & 0.9 & $570 \pm 10$ & 577 & 0.9 \\
\hline $\mathrm{Cr}$ & $17 \pm 3$ & 17.1 & 4.2 & $18 \pm 4$ & 16.1 & 4.5 & $20.9 \pm 0.7$ & 20.4 & 2.5 & $13.3 \pm 0.01^{*}$ & 14.9 & 4.3 \\
\hline Co & $2900 \pm 200$ & 3013 & 4.6 & $1700 \pm 100$ & 1766 & 1.3 & $3110 \pm 11$ & 3327 & 0.8 & $2240 \pm 11$ & 2387 & 1.2 \\
\hline $\mathrm{Ni}$ & $10200 \pm 800$ & 10752 & 4.2 & $15500 \pm 700$ & 15760 & 1.5 & $6360 \pm 24$ & 6536 & 0.8 & $13400 \pm 64$ & 13369 & 1.0 \\
\hline $\mathrm{Cu}$ & $6900 \pm 400$ & 7191 & 4.0 & $13600 \pm 500$ & 14390 & 1.5 & $1100 \pm 10$ & 1143 & 1.3 & $11500 \pm 49$ & 11731 & 0.9 \\
\hline $\mathrm{Zn}$ & $918 \pm 66$ & 907 & 4.0 & $1600 \pm 100$ & 1506 & 2.2 & $590 \pm 5$ & 584 & 1.2 & $1600 \pm 6$ & 1630 & 1.0 \\
\hline $\mathrm{Rb}$ & $16 \pm 2$ & 16.7 & 4.4 & $17 \pm 3$ & 17.2 & 1.2 & $10.6 \pm 0.1^{*}$ & 10.4 & 1.4 & $23.7 \pm 0.7^{*}$ & 24.9 & 2.2 \\
\hline $\mathrm{Sr}$ & $869 \pm 74$ & 854 & 2.3 & $561 \pm 62$ & 550 & 1.8 & $1750 \pm 14$ & 1737 & 1.2 & $680 \pm 3$ & 689 & 1.9 \\
\hline $\mathrm{Y}$ & $133 \pm 6$ & 140 & 1.6 & $84 \pm 3$ & 90.2 & 1.6 & $120 \pm 1^{*}$ & 117 & 1.1 & $90.0 \pm 0.6^{*}$ & 92.2 & 1.7 \\
\hline $\mathrm{Zr}$ & $618 \pm 58$ & 616 & 4.4 & $256 \pm 31$ & 253 & 1.7 & $310 \pm 3^{*}$ & 310 & 0.9 & $280 \pm 1^{*}$ & 285 & 1.4 \\
\hline $\mathrm{Nb}$ & $48 \pm 8$ & 49.8 & 3.4 & $21 \pm 3$ & 20.1 & 1.1 & $43.1 \pm 1.1^{*}$ & 43.9 & 0.9 & $21.3 \pm 0.1^{*}$ & 21.9 & 1.6 \\
\hline Mo & $473 \pm 33$ & 467 & 4.6 & $622 \pm 37$ & 607 & 1.6 & $448 \pm 9$ & 457 & 2.4 & $760 \pm 4$ & 739 & 4.2 \\
\hline $\mathrm{Cd}$ & $10 \pm 2$ & 10.1 & 1.5 & $23 \pm 3$ & 22.2 & 1.2 & $7.50 \pm 0.16^{*}$ & 7.87 & 1.1 & $22.6 \pm 0.3^{*}$ & 23.3 & 2.1 \\
\hline Cs & $0.84 \pm 0.08$ & 0.84 & 1.6 & $1.2 \pm 0.3$ & 1.23 & 1.5 & $0.61 \pm 0.01^{*}$ & 0.60 & 1.8 & $1.80 \pm 0.01^{*}$ & 1.83 & 2.0 \\
\hline $\mathrm{Ba}$ & $1800 \pm 100$ & 1781 & 1.9 & $2400 \pm 200$ & 2368 & 1.4 & $1670 \pm 31$ & 1665 & 0.7 & $3350 \pm 28$ & 3436 & 2.1 \\
\hline $\mathrm{La}$ & $184 \pm 22$ & 181 & 1.4 & $96 \pm 10$ & 96.0 & 1.7 & 120 & 119 & 0.8 & 104 & 110 & 1.5 \\
\hline $\mathrm{Ce}$ & $620 \pm 60$ & 626 & 1.2 & $249 \pm 21$ & 256 & 2.0 & 730 & 721 & 1.5 & 290 & 293 & 1.6 \\
\hline $\operatorname{Pr}$ & $49 \pm 5$ & 47.0 & 1.8 & $29 \pm 2$ & 30.0 & 1.7 & $25.0 \pm 0.01^{*}$ & 24.8 & 1.1 & $31.0 \pm 0.2^{*}$ & 33.4 & 1.6 \\
\hline $\mathrm{Nd}$ & $198 \pm 22$ & 199 & 1.8 & $121 \pm 15$ & 122 & 1.5 & 94 & 93.9 & 1.4 & 120 & 120 & 1.7 \\
\hline $\mathrm{Sm}$ & $46 \pm 5$ & 47.9 & 2.1 & $31 \pm 2$ & 31.9 & 1.3 & 21 & 21.3 & 1.1 & 30 & 30.8 & 1.4 \\
\hline $\mathrm{Eu}$ & $11 \pm 1$ & 11.2 & 1.7 & $7.6 \pm 0.7$ & 7.33 & 3.0 & 5 & 5.18 & 1.7 & 7.5 & 7.83 & 2.5 \\
\hline Gd & $48 \pm 7$ & 47.0 & 2.1 & $28 \pm 4$ & 29.1 & 2.0 & 26 & 25.6 & 1.4 & 28 & 29.8 & 1.4 \\
\hline $\mathrm{Tb}$ & $7.6 \pm 0.8$ & 7.38 & 2.8 & $4.6 \pm 0.5$ & 4.66 & 1.3 & $4.00 \pm 0.07^{*}$ & 4.04 & 1.0 & $4.90 \pm 0.02^{*}$ & 4.92 & 1.9 \\
\hline Dy & $42 \pm 3$ & 38.5 & 2.2 & $27 \pm 3$ & 25.3 & 1.0 & 23 & 22.1 & 1.2 & 27 & 26.2 & 1.8 \\
\hline Ho & $8.2 \pm 0.6$ & 7.80 & 2.2 & $5.1 \pm 0.3$ & 5.03 & 1.3 & $5.00 \pm 0.01^{*}$ & 5.00 & 1.1 & $5.00 \pm 0.01^{*}$ & 5.19 & 1.4 \\
\hline $\mathrm{Er}$ & $21 \pm 2$ & 20.0 & 2.4 & $13 \pm 1$ & 12.7 & 1.2 & 12 & 12.7 & 1.2 & 12 & 12.2 & 1.5 \\
\hline $\mathrm{Tm}$ & $3.1 \pm 0.4$ & 3.16 & 2.6 & $1.9 \pm 0.1$ & 1.97 & 1.5 & $2.00 \pm 0.06^{*}$ & 2.06 & 1.0 & $1.90 \pm 0.02^{*}$ & 1.93 & 2.3 \\
\hline $\mathrm{Yb}$ & $20 \pm 2$ & 19.1 & 2.6 & $12 \pm 1$ & 12.1 & 1.5 & 14 & 13.6 & 0.9 & 13 & 12.5 & 2.0 \\
\hline $\mathrm{Lu}$ & $2.9 \pm 0.4$ & 2.89 & 2.1 & $1.8 \pm 0.2$ & 1.82 & 1.7 & 2.2 & 2.11 & 1.6 & 1.8 & 1.82 & 1.5 \\
\hline Hf & $10 \pm 2$ & 9.93 & 2.3 & $3.9 \pm 0.5$ & 3.83 & 2.1 & $5.80 \pm 0.66^{*}$ & 5.68 & 1.9 & $4.20 \pm 0.02^{*}$ & 4.11 & 1.9 \\
\hline $\mathrm{Ta}$ & & 0.51 & 4.8 & & 0.29 & 2.2 & $0.76 \pm 0.03^{*}$ & 0.78 & 2.1 & $0.33 \pm 0.01^{*}$ & 0.34 & 1.7 \\
\hline W & $67 \pm 5$ & 65.5 & 1.7 & $61 \pm 5$ & 62.9 & 1.3 & $87.0 \pm 0.8^{*}$ & 87.8 & 0.8 & $57.8 \pm 1.1^{*}$ & 56.7 & 0.7 \\
\hline $\mathrm{Pb}$ & $709 \pm 44$ & 677 & 1.1 & $328 \pm 33$ & 319 & 1.2 & 846 & 876 & 1.1 & $560 \pm 6$ & 573 & 1.7 \\
\hline $\mathrm{Bi}$ & $15 \pm 1$ & 14.9 & 1.4 & $5 \pm 1$ & 5.09 & 1.7 & $10.2 \pm 0.1^{*}$ & 10.0 & 1.2 & $5.80 \pm 0.40^{*}$ & 5.72 & 3.2 \\
\hline Th & $26 \pm 4$ & 22.8 & 1.2 & $15 \pm 2$ & 14.3 & 1.8 & $25.1 \pm 0.6^{*}$ & 23.0 & 1.5 & $16.7 \pm 0.2^{*}$ & 15.8 & 1.8 \\
\hline $\mathrm{U}$ & $6.2 \pm 1.0$ & 6.04 & 1.5 & $3.8 \pm 0.7$ & 3.70 & 1.8 & $7.00 \pm 0.08^{*}$ & 7.22 & 1.5 & $4.00 \pm 0.04^{*}$ & 3.94 & 2.5 \\
\hline
\end{tabular}

*Data from Reference (62). 
Nature Science Foundation of China (Grant No. 41476044), the International Partnership Program of Chinese Academy of Sciences (Grant No. 133137KYSB20170003), and the Special Fund for the Taishan Scholar Program of Shandong Province (Grant No. ts201511061).

Received July 23, 2019.

\section{REFERENCES}

1. A. B. Valsangkar and J. M. S. Rebello, Significance of Size in Occurrence, Mar. Georesour. Geotec. 33, 135 (2015).

2. A. B. Valsangkar and J. M. S. Rebello, Mar. Georesour. Geotec. 34, 542 (2016).

3. E. Marino, F.J. González, L. Somoza, R. Lunar, L. Ortega, J.T. Vázquez, J. Reyes, and E. Bellido, Ore Geol. Rev. 87, 41 (2017).

4. J. R. Hein, K. Mizell, A. Koschinsky, and T. A. Conrad, Ore Geol. Rev. 51, 1 (2013).

5. A. V. Wegorzewski, T. Kuhn, R. Dohrmann, R. Wirth, and S. Grangeon, Am. Mineral. 100, 2497 (2015).

6. N. Konstantinova, G. Cherkashov, J. R. Hein, J. Mirão, L. Dias, P. Madureira, V. Kuznetsov, and F. Maksimov, Ore Geol. Rev. 87, 88 (2017).

7. K. Azami, N. Hirano, S. Machida, K. Yasukawa, Y. Kato, Chemical Geology 493, 224 (2018).

8. Y. Zhong, Q. S. Liu, Z. Chen, F. J. González, J. R. Hein, J. Zhang, and L. F. Zhong, Mar. Geol. 410, 146 (2019).

9. Y. Kato, K. Fujinaga, T. Nozaki, H. Osawa, K. Nakamura, and R. Ono, Resour. Geol. 55(4), 291 (2005).

10. M. A. Marcus, K. J. Edwards, B. Gueguen, S. C. Fakra, G. Horn, N. A. Jelinski, O. Rouxel, J. Sorensen, B. M. Toner, Geochim. Cosmochim. Acta, 171, 61 (2015).

11. K. Nishi, A. Usui, Y. Nakasato, and H. Yasuda, Ore Geol. Rev. 87, 62
(2017).

12. P. A. Knoop, R. M. Owen, and C. L. Morgan, Mar. Geol. 147, 1 (1998).

13. K. Mewes, J. M. Mogollón, A. Picard, C. Rühlemann, T. Kuhn, K. Nöthen, and S. Kasten, Deep-Sea Res. PT I, 191, 125 (2014).

14. A. V. Wegorzewski, and T. Kuhn, Mar. Geol. 357, 123 (2014).

15. C. Heller, T. Kuhn, G. J. M. Versteegh, A. V. Wegorzewski, S. Kasten, Deep-Sea Res. PT I, 142, 16 (2018).

16. S. T. Neil, Geostandards Newsl. 4(2), 205 (1980).

17. S. Terashima, A. Usui, and N. Imai, Geostandards Newsl. 19(2), 221 (1995).

18. D. S. Cronan, J. Geophys. Res. 80(27), 3831 (1975).

19. M. Lyle, J. Dymond, and G. R. Heath, Earth Planet Sc. Lett. 35, 55 (1977).

20. D. S. Cronan and S. A. Moorby, J. Geol. Soc. London 138, 527 (1981).

21. G. P. Glasby and T. Thijssen, TMPM Tschermaks Min. Petr. Mitt. 30, 205 (1982).

22. J. Dymond, M. Lyle, B. Finney, D. Z. Piper, K. Murphy, R. Conard, and N. Pisias, Geochim. Cosmochim. Acta, 48, 931 (1984).

23. A. Usui, Mar. Geol. 54, 27 (1983).

24. R. Banerjee and R. Mukhopadhyay, Geo-Mar. Lett. 11, 39 (1991).

25. A. B. Valsangkar and S. M. Karisiddaiah, Mar. Georesour. Geotec. 11, 87 (1993).

26. J. C. Chen and Y. C. Yao, J. Southeast Asian Earth Sci. 11(1), 61 (1995).

27. P. A. knop, R. M. Owen, and C. L. Morgan, Mar. Geol. 147, 1 (1998).

28. R. Banerjee, S. Roy, S. Dasgupta, S. Mukhopadhyay, H. Miura, Mar. Geol. 157, 145 (1999).

29. D. Z. Piper and M. E. Williamson, Mar. Geol. 40, 255 (1981).

30. A. B. Valsangkar, N. H. Khadge, and J. A. Erwin Desa, Mar. Geol. 103, 361 (1992).

31. S. Q. Guo and W. H. Sun, Acta Geol.

\section{Atomic}

Sin-Engl. 5(4), 371 (1992).

32. J. R. Hein, F. Spinardi, N. Okamoto, K. Mizell, D. Thorburn, and A. Tawake, Ore Geol. Rev. 68, 97 (2015).

33. D. Zawadzki, L. Maciag, R. A. Kotlinski, G. A. Kozub-Budzyn, A. Piestrzynski, R. Wróbel, Ore Geol. Rev. 101, 520 (2018)

34. T. Conrad, J. R. Hein, A. Paytan, and D. A. Clague, Ore Geol. Rev. 87,25 (2017).

35. T. Kuhn, M. Bau, N. Blum, and P. Halbach, Earth Planet Sc. Lett. 163, 207 (1998).

36. D. S. Cronan and R. A. Hodkinson, J. Geol. Soc. London 151, 391 (1994).

37. J. R. Hein, A. Koschinsky, P. Halbach, F. T. Manheim, M. Bau, J. Kang, and N. Lubick, J. Geol. Soc. London, Special Publications, 119, 123 (1997).

38. S. kasten, G. P. Glasby, H. D. Schulz, G. Friedrich, and S. I. Andreev, Mar. Geol. 146, 33 (1998).

39. J. N. Pattan and G. Parthiban, J. Geol. Soc. India 68, 605-609 (2006).

40. C. Canet, R. M. Prol-Ledesma, W. L. Bandy, P. Schaaf, C. Linares, A. Camprubí, E. Tauler, and C. Mortera-Gutiérrez, Mar. Geol. 251, 47 (2008)

41. J. R. Hein, T. A. Conrad, M. Frank, M. Christl, and W. W. Sager, Geochem. Geophys. Geosys. 13(10), 1 (2012).

42. K. Schmidt, M. Bau, J. R. Hein and A. Koschinsky, Geochim. Cosmochim. Acta 140, 468 (2014).

43. N. V. Astakhova, E. A. Lopatnikov, and I. B. Tsoy, J. Volcanol. Seismol. 9(6), 358 (2015).

44. B. Gueguen, O. Rouxel, M. Rouget, C. Bollinger, E. Ponzevera, Y. Germain, and Y. Fouquet, Geochim. Cosmochim. Acta 189, 214 (2016).

45. T. Nozaki, A. Tokumaru, Y. Takaya, Y. Kato, K. Suzuki, and T. Urabe, Geochem. J. 50, 527 (2016).

46. N. konstantinova, G. Cherkashov, J. R. Hein, J. Mirão, L. Dias, P. Madureira, V. Kuznetsov, and F. Maksimov, Ore Geol. Rev. 87, 88 
(2017).

47. P. Josso, E. Pelleter, O. Pourret, Y. Fouquet, J. Etoubleau, S. Cheron, and C. Bollinger, Ore Geol. Rev. 87,3 (2017).

48. A. Menendez, R. H. James, A. Lichtschlag, D. Connelly, and K. Peel, Mar. Geol. 409, 1 (2019).

49. O. S. Vereshchagin, E. N. Perova, A I. Brusnitsyn, V. B. Ershova, A. K. Khydoley, V. V. Shilovskikh, and E. V. Molchanova, Ore Geol. Rev. 106, 192 (2019).

50. B. Zawisza, K. Pytlakowska, B. Feist, M. Polowniak, A. Kita, R. Sitko, J. Anal. At. Spectrom. 26, 2373 (2011)

51. Tel-Cayan, Z. Ullah, M. Ozturk, M. Yabanli, F. Aydin, and M. E. Duru, At. Spectrosc. 39(1), 29 (2018).

52. Y.T. Li, W. Guo, Z. C. Hu, L. L. Jin, S. H. Hu, and Q. H. Guo, J. Agric. Food Chem., 67, 935 (2019)

53. Z. W. Wu, W. Guo, L. L. Jin, and S. H. Hu, Microchem. J. 142, 251 (2018)

54. E. Arica, B. Yuksel, I. Yener, I. Dolak, E. Gok, and E. Yilmaz, Atom. Spectrosc. 39(2), 62 (2018).

55. W. Guo, L. L. Jin, S. H. Hu, and Q. H. Guo, J. Agric. Food Chem., 65, 3406 (2017)

56. W. Guo, Z. W. Wu, S. H. Hu, L. L. Jin, K. Y. Qiu, Q. H. Guo, and Y. Q. Gan, RSC Adv., 6, 47394 (2017)

57. Y. E. Peng, W. Guo, J. Zhang, Q. H. Guo, L. L. Jin, and S. H. Hu, Microchem. J., 124, 127 (2016)

58. W. Guo, S. H. Hu, Z. W. Wu, G. Y. Lan, L. L. Jin, X. G. Pang, J. C. Zhan, B. Chen, and Z. Y. Tang, J. Anal. At. Spectrom. 30, 986 (2015)

59. W. Guo, S. H. Hu, Y. F. Xiao, H. F Zhang, and X. J. Xie, Chemosphere, 81, 1463 (2010)

60. B.Yuksel, and E. Arica, At. Spectrosc. 39(5), 179 (2018).

61. A. Usui, M. Bau, and T. Yamazaki, Mar. Geol. 141, 269 (1997).

62. M. D. Axelsson, I. Rodushkin, J. Ingri, and B. Öhlander, Analyst 127, 76 (2002).

63. S. Chen, X. B. Yin, X. Y. Wang, X. Huang, Y. Ma, K. Guo, and Z. G.
Zeng, Ore Geol. Rev. 95, 118 (2018).

64. V. Balaram, K. V. Anjaiah, and M. R. P. Reddy, Analyst 120, 1401 (1995).

65. J. N. Pattan, G. Parthiban, A. Amonkar, S. A. Shaikh, and S. J. Sankar, Mar. Georesour. Geotec. doi:

10.1080/1064119X.2017.1297878 (2017).

66. A. Usui, K. Nishi, H. Sato, Y. Nakasato, B. Thornton, T. Kashiwabara, A. Tokumaru, A. Sakaguchi, K. Yamaoka, S. Kato, S. Nitahara, K. Suzuki, K. Iijima, T. Urabe, Ore Geol. Rev. 87, 71 (2017).

67. L. Qi, J. Hu, and D. C. Gregoire. Talanta 51, 507 (2000).

68. W. Diegor, H. Longerich, T. Abrajano, and I. Horn, Anal. Chim. Acta 431, 195 (2001).

69. L. Qi, J. F. Gao, X. W. Huang, J. Hu, M. F. Zhou, and H. Zhong, J. Anal. At. Spectrom. 26, 1900 (2011).

70. X. B. Yin, X. Y. Wang, S. Chen, Y. Ma, K. Guo, and Z.G. Zeng, At. Spectrosc. 39(4), 137 (2018). 